\title{
OPTIMUM TUNING PARAMETERS OF TUNED MASS DAMPERS FOR VIBRATION CONTROL OF IRREGULAR HIGHRISE BUILDING STRUCTURES
}

\author{
Mariantonieta GUTIERREZ SOTO, Hojjat ADELI \\ Department of Civil, Environmental, and Geodetic Engineering, the Ohio State University, \\ 470 Hitchcock Hall, 2070 Neil Avenue, Columbus, OH 43210, USA
}

Received 23 Aug 2014; accepted 15 Sep 2014

\begin{abstract}
Tall buildings have become increasingly one-of-a-kind signature structures that are often irregular in plan and elevation with complicated dynamic behavior. Vibration control of irregular highrise building structures using a recently developed tuned mass dampers (TMD), the bidirectional TMD (BTMD), is investigated. A key issue for effective implementation of a TMD is the determination of their tuning parameters. Eight different sets of equations for tuning the parameters of TMDs are investigated using a 5-story building with plan and elevation irregularity, and a 15-story and a 20 -story building with plan irregularity subjected to seismic loading. Appropriate equations are recommended for building structures with a fundamental period of vibrations of greater than one second.
\end{abstract}

Keywords: vibration control, tuned mass damper, highrise building, irregular structure.

\section{Introduction}

In recent years clients for tall buildings have increasingly been demanding one-of-kind signatures that are often irregular in plan and elevation with complicated dynamic behavior (Wang, Adeli 2014). An innovative approach to mitigate the vibration of structures during dynamic wind and earthquake events is the use of tuned mass dampers (TMDs). For example, Kang et al. (2012) evaluate performance of TMD installed on a 39-story, $184.6 \mathrm{~m}$ steel building located in Incheon, Korea under typhoon using system identification (Cen et al. 2013) and inverse wind load estimation. Amini et al. (2013) present optimal vibration control of a 10-storey shear-frame building structure using an active TMD and a wavelet-based (Ghodrati Amiri et al. 2012; Xiang, Liang 2012; Lin et al. 2012; Acharya et al. 2012; Kodogiannis et al. 2013) control algorithm and particle swarm optimization (Tao et al. 2012; Shafahi, Bagherian 2013; Hsu 2013). Ghaemmaghami et al. (2013) study dynamic behavior of annular tuned liquid dampers in tall wind towers. A review of TMDs is presented by Gutierrez Soto and Adeli (2013).

Vibration control of structures can be divided into passive, semi-active, and active control (Ko et al. 2012; Hemami et al. 2012; Rodriguez-Seda et al. 2012; Rigatos 2013; Boutalis et al. 2013; El-Khoury, Adeli 2013). Passive dampers have proven to be a good practical option for retrofitting of historic buildings (Branco, Guerreiro 2011; Nawrotzki 2006) and can be implemented on existing buildings with relatively modest rehabilitation. Nawrotzki (2008) points out adding TMDs create a dynamic upgrade in existing bridges and buildings that increases structural safety and improves serviceability and comfort conditions.

Irregular structures behave in a complex manner during strong ground motions and their vibration control is of particular interest (Lei et al. 2012; Nigdeli, Boduroğlu 2013). Kim and Adeli (2005a, b) investigate vibration control of irregular highrise building structures under various seismic excitations using a hybrid control system consisting of a passive supplementary damping system and a semi-active tuned liquid column damper (TLCD) system. They use a novel wavelet-based optimal control algorithm (Adeli, Kim 2004; Kim, Adeli 2004) to find the optimum control forces. Simulation results for control of two multistory moment-resisting space steel structures with vertical and plan irregularities show clearly that the hybrid damper-TLCD control system significantly reduces responses of irregular buildings subjected to various earthquake ground motions. Bitaraf et al. (2012) present active and semi-active adaptive control for undamaged and damaged building structures under seismic motions. Aldemir et al. (2012) propose a simple method to obtain the suboptimal passive damping and stiffness parameters from the optimal control gain matrix. They also propose a new performance index in order to consider the mechanical energy of the structure, control and the seismic energies simultaneously in the minimization procedure. The resulting closed-loop control algorithm does not require the solution of the nonlinear Riccati equation (Saleh, Adeli 1997; Adeli, Saleh 1999). They present examples of multistory frames subjected to seismic excitations.

Almazan et al. (2012) study the performance and placement of one or more TMDs in asymmetric buildings 
using four different examples including a threedimensional (3D) 15-story RC structure with plan irregularity subjected to seismic loading with the goal of minimizing the inter-story displacement or drift. They use the Kanai-Tajimi spectrum to model the seismic excitation and place 1 or 2 TMDs on the roof. For asymmetric structures, they conclude that the optimum TMD frequency and location on the roof depend on structural lateral and torsional stiffnesses, eccentricity between centers of mass and rigidity and the frequency content of the ground motion; and the optimum location is near the geometric center of the plan. They also conclude: "if the uncertainty associated to the dynamic parameters of the main structure is ignored, a significant improvement would not be obtained by adding a second TMD".

$\mathrm{Lu}$ et al. (2013) present vibration control of The Shanghai World Financial Center Tower, currently the tallest building in China, with a height of $492 \mathrm{~m}$ under wind using two Active Tuned Mass Dampers (AMTD) place on the 90th floor. AMTDs are employed to mitigate wind vibrations only. During earthquakes actuators are turned off and ATMDs behave like passive TMDs. The authors report a reduction in the wind acceleration response of up to $60 \%$ when the wind speed is below the design value.

It was noted by Villaverde (1985) that vibration absorbers yield a desired response subjected to earthquake loading only if the appropriate parameters of vibration absorber device are selected. Equations for parameters of vibration dampers have evolved over the years. Early equations were based on harmonic excitations acting directly on the mass which is different when earthquake excitation is acted at the base.

Vibration control of irregular highrise building structures using a recently developed TMD, the bidirectional TMD (BTMD), is investigated in this paper. Eight different sets of equations for tuning the parameters of tuned mass dampers (TMDs) are investigated using a 5 -story building with plan and elevation irregularity, and a 15 -story and a 20 -story building with plan irregularity subjected to seismic loading. The BTMD is combination of two cables forming a Y-shape connected to the mass at the middle, and a friction damper connected to the mass from the bottom.

\section{Selection of optimum parameters values for a TMD}

Different researchers have presented equations for the optimum values of the parameters of the TMD using different criteria or approaches. A summary is provided in Table 1. Most researchers present optimum values of the damping and frequency ratios based on a given mass ratio.

Table 1. Equations for finding the optimum tuning parameters of a TMD

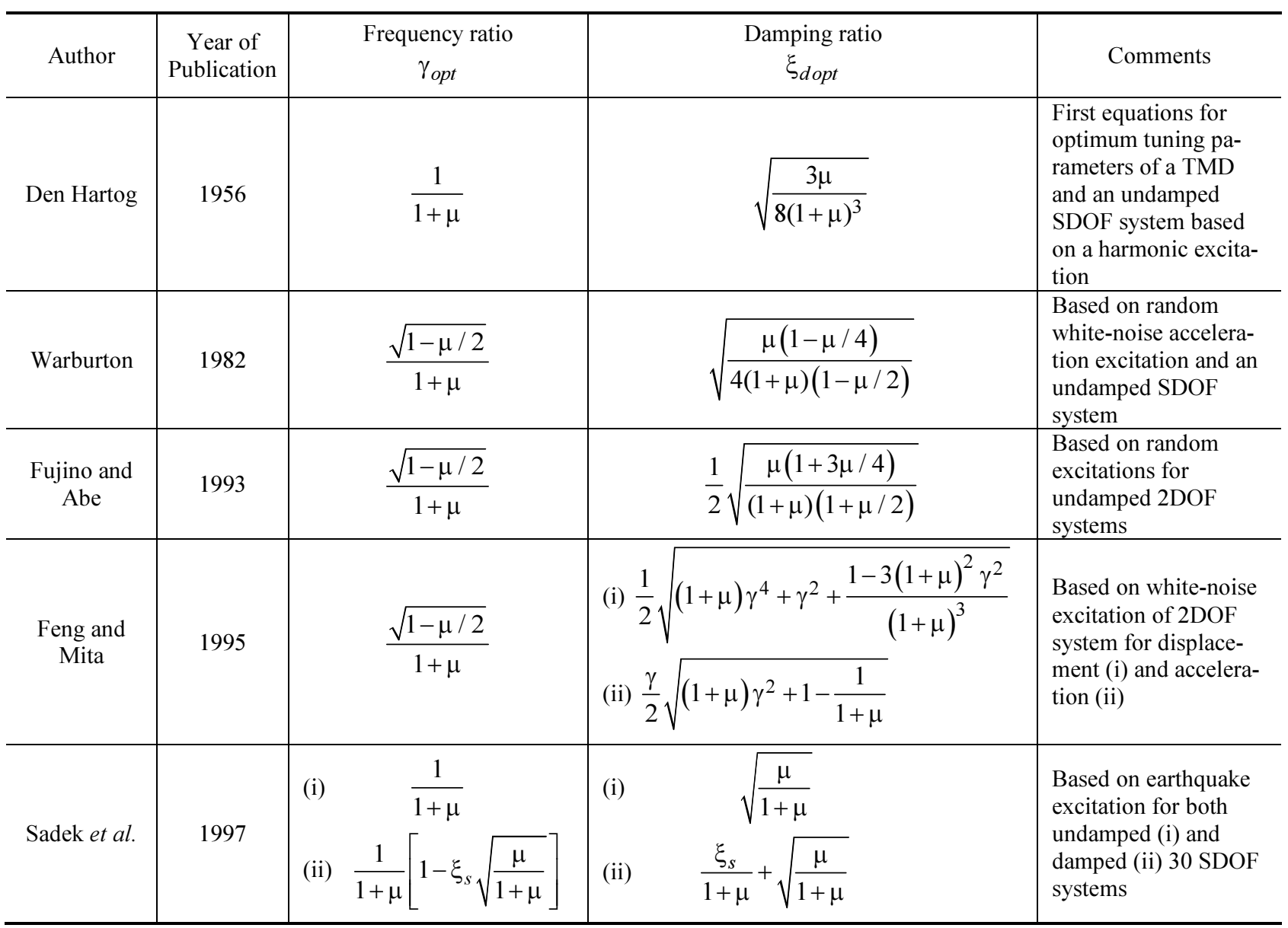


Continued Table 1

\begin{tabular}{|c|c|c|c|c|}
\hline Author & $\begin{array}{l}\text { Year of } \\
\text { Publication }\end{array}$ & $\begin{array}{c}\text { Frequency ratio } \\
\gamma_{\text {opt }}\end{array}$ & $\begin{array}{c}\text { Damping ratio } \\
\xi_{\text {dopt }}\end{array}$ & Comments \\
\hline Rudinger & 2006 & $\sqrt{\frac{(2+\mu)}{2(1+\mu)^{2}}}$ & $\sqrt{\frac{\mu(4+3 \mu)}{4(1+\mu)^{3}}}$ & $\begin{array}{l}\text { Based on white noise } \\
\text { excitation on un- } \\
\text { damped and damped } \\
\text { linear and nonlinear } \\
\text { SDOF systems with } \\
\text { linear damping }=1\end{array}$ \\
\hline $\begin{array}{l}\text { Krenk and } \\
\text { Hogsberg }\end{array}$ & 2008 & $\frac{1}{1+\mu}$ & $\frac{1}{2} \sqrt{\frac{\mu}{(1+\mu)}}$ & $\begin{array}{l}\text { Based on force and } \\
\text { white noise accelera- } \\
\text { tion excitation on } \\
\text { undamped and } \\
\text { damped 2DOF sys- } \\
\text { tems }\end{array}$ \\
\hline Hoang et al. & 2008 & $\begin{array}{l}\text { (i) } \frac{\sqrt{(1-6 \mu)\left(1+\mu^{2}\right)}}{1+\mu}-0.7 \xi_{s} \\
\text { (ii) } \frac{\sqrt{\left(1-\frac{\delta \mu}{6}\right)}}{1+\mu}-\frac{0.7 \xi_{s}}{1-\frac{\mu}{2}} \\
\text { (iii) } \frac{\sqrt{(1-\mu / 2)}}{1+\mu}-\frac{0.7 \xi_{s}}{1-\mu / 2}\end{array}$ & $\begin{array}{l}\text { (i) } \frac{\sqrt{\mu\left(1+2.5 \mu+2 \mu^{2}\right)}}{2(1+2.7 \mu)} \\
\text { (ii) } \sqrt{\frac{\mu\left(1-\frac{\mu}{4}\right)}{4(1+\mu)\left(1-\frac{\mu}{2}\right)}}+0.25 \mu \xi_{s} \\
\text { (iii) } \sqrt{\frac{\mu(1-\mu / 4)}{4(1+\mu)(1-\mu / 2)}}+0.25 \mu \xi_{s}\end{array}$ & $\begin{array}{l}\text { Based on seismic } \\
\text { excitation of a } \\
\text { damped SDOF for } \\
\text { ranges of ground } \\
\text { frequency ratio of } \\
\delta=\omega_{\mathrm{g}} / \omega_{\mathrm{s}} \\
\text { (i) } \delta=1 \\
\text { (ii) } 1<\delta<3 \\
\text { (iii) } \delta \geq 3\end{array}$ \\
\hline
\end{tabular}

Den Hartog (1956) derived equations by minimizing the response of an undamped single-degree-of-freedom (SDOF) system subjected to sinusoidal loading. The author showed how damper and spring coefficients can be determined to minimize vibration for a specific structural mode.

Warburton (1982) uses Den Hartog's approach and broadband optimization to derive equations considering harmonic and white noise random excitations directly on a SDOF system based on the notion that the average damping ratios of the resonant modes between the uncontrolled structure and the TMD is approximately equal to the effective damping ratio of a building with TMD.

Villaverde (1985) derived equations for a TMD with high damping and small mass ratios by minimizing the dynamic response of a 2D three-story frame and a 3D 10story building subjected to seismic loading.

Fujino and Abe (1993) present four sets of equations for optimum tuning parameters of a 2DOF system for four different cases: free vibration, harmonic, selfexcited, and random excitations based on a modification of the 2DOF dynamic characterization proposed by Igusa and Der Kiureghian (1985) using the mean-square values of perturbation solutions of displacement responses assuming both mass and structural damping ratios of less than two percent. The equations for the case of random excitations are included in Table 1.

Feng and Mita (1995) proposed two sets of equations, one for displacement and the other for acceleration, for the optimum values of frequency and damping ratios of a TMD attached to a 2 DOF system by minimizing the dynamic response in terms of mean square values of displacement and acceleration. They study the performance of their equations on a $200-\mathrm{m}$ tall building 2D frame with a structural damping ratio of 0.02 subjected to earthquake excitations.

Sadek et al. (1997) modified the equations proposed by Villaverde (1985) and use curve fitting to find optimum parameters of the TMD system such that the first two modes of the controlled structure have the same damping ratio with a value equal to greater than the average damping ratio of TMD and structure alone. Their formulation varies from previous authors in that it includes the structural damping ratio of the primary structural system $\left(\xi_{s}\right)$. The authors also investigated the optimum parameters for MDOF using a factor that takes into consideration the amplitude of the first mode shape of the structure.

Rudinger (2006) used statistical linearization to derive TMD optimum tuning parameter equations for a damped SDOF system subjected to white noise excitation. The author concludes TMD optimum tuning parameters are the same for undamped and damped systems that behave linearly. On the contrary, optimal parameters for a nonlinear system with TMD are dependent on structural damping and excitation intensity (vibration amplitude).

Krenk and Hogsberg (2008) use an approximation technique with minimum standard deviation to obtain optimum tuning equations for undamped and damped 2DOF systems subjected to force and acceleration excitations independent of the structural damping ratio. Their approximation suggests that optimal performance can be obtained without considering the structural damping of the primary system in formulation of tuning and frequency ratios. 
Hoang et al. (2008) present equations for optimum parameters of a TMD for a SDOF system subjected to seismic excitation for different ranges of the ratio of the dominant ground frequency $\left(\omega_{\mathrm{g}}\right)$ to structural frequency $\left(\omega_{\mathrm{S}}\right), \delta=\omega_{\mathrm{g}} / \omega_{\mathrm{S}}$, using a nonlinear programming technique (Adeli, Soegiarso 1999; Adeli, Sarma 2006) that follows the Davidon-Fletcher-Powell algorithm (Hoang, Warnitachai 2005). The idea is to have sitespecific parameters thus taking into account the type of soil on which a structure is built. In their formulation, the authors simulate artificial earthquakes using the KanaiTajimi model and choose a specific ground frequency. Their formulas are separated on a specific range of ground frequency ratio, but in reality the range of ground frequencies in an earthquake cannot be known a priori. The authors presented a numerical example where they studied the effect of large mass ratios for TMD in a bridge subjected to earthquake loading. They noted that the: "optimal TMD has lower tuning frequency and higher damping ratio with increasing mass ratio". They also concluded that using a large mass ratio can help against parameter uncertainties that occur between theoretical model and the actual practical implementation. In their example, they use a mass ratio of $77 \%$ and provided response reduction for their example, yet using such high mass ratio on a building such as a TMD on roof can influence the practicality and constructability of the design.

\section{Bidirectional tuned mass damper}

Almazan et al. (2007) proposed a bidirectional TMD (BTMD) device and applied it to control vibrations of a 25 -story reinforced concrete $3 \mathrm{D}$ regular frame and an $80-\mathrm{m}$ by $3-\mathrm{m}$ diameter thin-walled cylindrical steel structure subjected to seismic loading. This device is a combination of two cables forming a Y-shape connecting to the mass at the middle, and a friction damper connected to the mass from the bottom (Fig. 1).

The tuning parameters of a BTMD are the mass $m_{d}$ and the lengths $L_{x}$ and $L_{y}$ of the cables from the mass to the fix support and to Y-intersection (Fig. 1) which are determined as follows:

$$
\begin{gathered}
L_{x}=\frac{g}{\gamma_{o p t}^{2} \omega_{s x}^{2}} ; \\
L_{y}=\frac{g}{\gamma_{o p t}^{2} \omega_{s y}^{2}} ; \\
\tilde{f}_{o}=\frac{f_{o}}{m_{d} g}=\frac{\left(\xi_{o p t}-\xi_{o}\right) \pi}{1-L_{x} / L_{f}},
\end{gathered}
$$

where $\omega_{s x}$ and $\omega_{\text {sy }}$ stand for the fundamental natural frequencies of the structure in the two principal directions considered. These frequencies are determined based on the dominance of the modal mass participation factor. The optimal slip force $\tilde{f}_{o}$ is obtained based on the equiv- alent damping ratio, $\xi_{e q}$ (which is set equal to $\xi_{\text {opt }}$ ). $\xi_{o}$ is the viscous damping ratio of the friction damper located at the connection and $L f$ is the remaining distance from the intersection to the floor. The optimum tuning parameters can be the same values used for a standard TMD presented in Table 1.

A mass ratio $(\mu)$ within the range of $3-5 \%$ has been recommended in the literature (Connor 2003). A mass ratio of $\mu=0.03$ and structural damping $\left(\xi_{s}\right)$ of 0.05 is recommended for steel structures (ASCE 2010) are used in this paper.

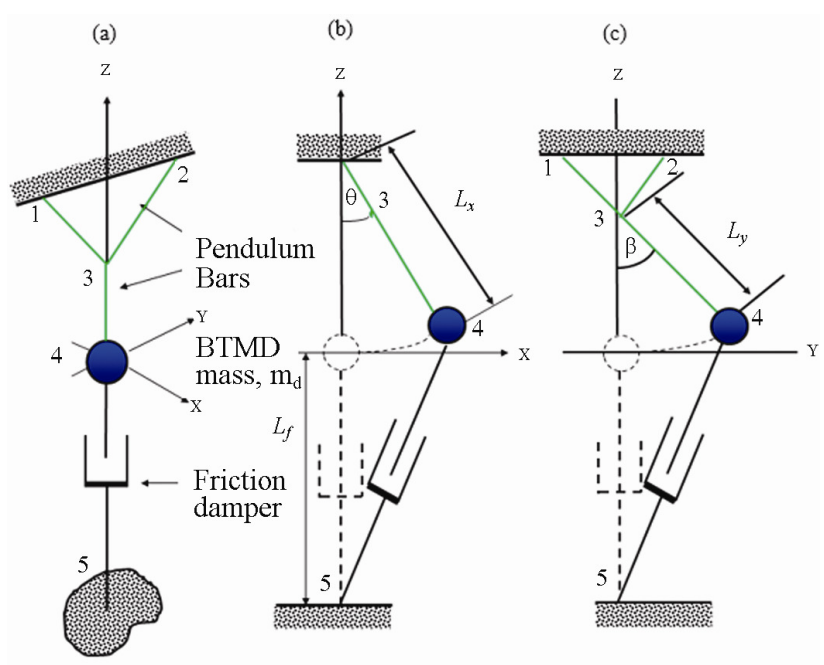

Fig. 1. Bidirectional Tuned Mass Damper (BTMD): (a) Threedimensional view; (b) view in the xz plane; (c) view in the $y z$ plane

\section{Comparison of equations for optimum BTMD tuning parameters}

In this section, eight different sets of equations for finding the optimum BTMD tuning parameters summarized in Table 1 are compared using three different irregular structures.

\subsection{Example 1: five-story 3D ordinary moment resisting steel frame with plan and elevation irregularity}

The 5-story 3D ordinary moment resisting steel frame with setbacks and an L-shape plan is shown in Figures 2 and 3. This example was originally created by Young and Adeli (2014). Roof and floor framing systems consist of steel beams and 6-in thick lightweight concrete over steel metal deck working as a rigid diaphragm. The loads on the structure include dead load from self-weight for steel members and concrete floors, additional dead load for roofing, partitions, furniture and other structure items (15 psf), cladding ( $25 \mathrm{psf})$, live load (50 psf) and wind load corresponding to $85 \mathrm{mph}$, gust factor 0.85 and exposure category $\mathrm{C}$. It is designed for a design acceleration spectrum of $0.28 \mathrm{~g}$, site class D and seismic category B (ASCE 2010). Centers of mass (CM) and centers of rigidity $(\mathrm{CR})$ are identified in Figure 3. 


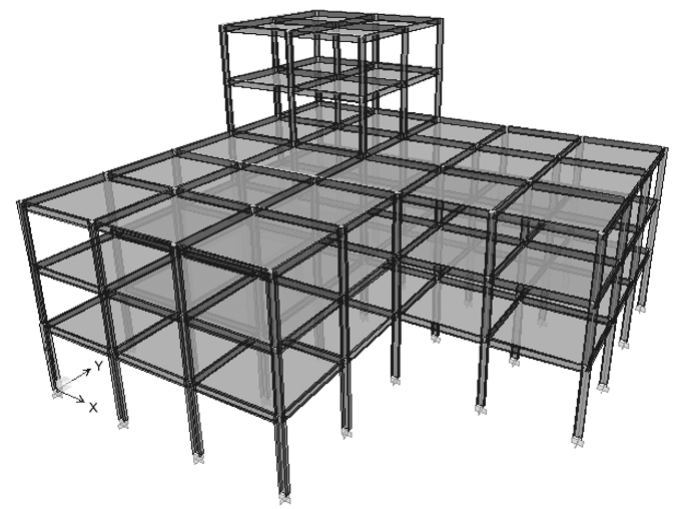

Fig. 2. Five-story irregular 3D building structure with setbacks and an L-shape plan

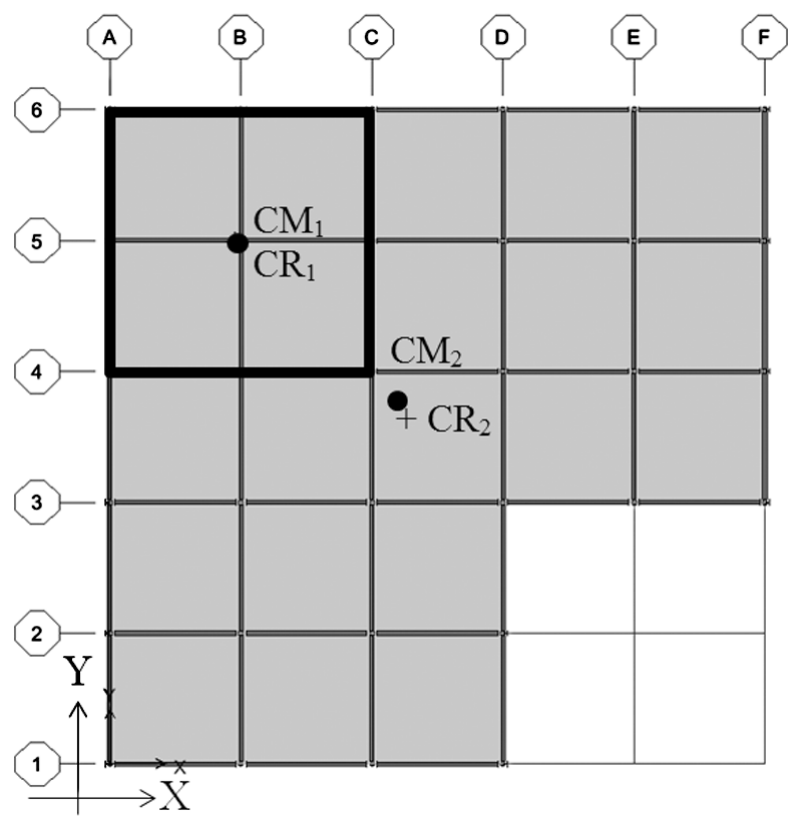

Fig. 3. Plan view of 5-story building $\left(+\mathrm{CR}_{1}=\right.$ center of rigidity of the top two floors, $+\mathrm{CR}_{2}=$ center of rigidity of the bottom three floors, $\bullet \mathrm{CM}_{1}=$ center of mass of the top two floors, $-\mathrm{CM}_{2}=$ center of mass of the bottom three floors)

Table 2 presents the modal response data for the first 7 modes of the uncontrolled structure. The more irregular the structure, the larger number of modes is needed for accurate determination of the dynamic response of the structure (Liang et al. 2012). In this example, the dominant modes, that is, the modes with the largest modal participation factors, are found to be the first two modes (their participation factors are identified in shaded boxes in Table 2).

The most dominant mode turns out to be the second mode of vibrations. As such, the parameters of BTMD are determined for the first two modes of vibrations and used for the comparative study in this paper. A BTMD is placed at the CR of the roof location (B-5 in Fig. 3). The uncontrolled structure is subjected to Loma Prieta, Northern California, earthquake of October 17, 1989, with Magnitude 7.1 (Station 58378) displayed in Figure 4 using twenty four different incident angles with increments of 15 degrees in the horizontal plane. The maximum absoliute displacement
Table 2. Free vibration modal response of the 5-story irregular building

\begin{tabular}{c|c|c|c|c}
\hline \multirow{2}{*}{ Mode } & \multirow{2}{*}{$\begin{array}{c}\text { Period } \\
(\mathrm{sec})\end{array}$} & \multicolumn{3}{|c}{ Modal Participation Factors } \\
\cline { 3 - 5 } & & $\begin{array}{c}\mathrm{X} \\
\text { Translation }\end{array}$ & $\begin{array}{c}\text { Y } \\
\text { Translation }\end{array}$ & $\begin{array}{c}\mathrm{Z} \\
\text { Torsion }\end{array}$ \\
\hline 1 & 0.807 & 0.001 & 0.470 & 0.036 \\
\hline 2 & 0.553 & 0.480 & 0.071 & 0.770 \\
\hline 3 & 0.502 & 0.150 & 0.360 & 0.021 \\
\hline 4 & 0.444 & 0.180 & 0.027 & 0.003 \\
\hline 5 & 0.279 & 0.052 & 0.000 & 0.016 \\
\hline 6 & 0.240 & 0.018 & 0.004 & 0.027 \\
\hline 7 & 0.183 & 0.047 & 0.027 & 0.023 \\
\hline & $\begin{array}{c}\text { Total } \\
\text { Sum }=\end{array}$ & 0.928 & 0.959 & 0.896 \\
\hline
\end{tabular}

was obtained for the incident angle of 75 degrees with respect to the X-axis shown in Figure 3. Next, the incident angle resolution was reduced to 5 degrees around the incident angle of 75 degrees between 60 and 90 degrees. The maximum absolute displacement was obtained for the incident angle of 80 degrees at joint A6-5. Each node is identified with a letter (indicating the grid in the N-S direction) followed by a number (indicating the grid in the E$\mathrm{W}$ direction), a dash, and a second number (indicating the floor number). For example, A6-5 indicates the node at the intersection of grid lines $A$ and 6 on the $5^{\text {th }}$ floor. The maximum absolute joint displacements in $\mathrm{cm}$ for different earthquake incident angles are depicted in Figure 5.

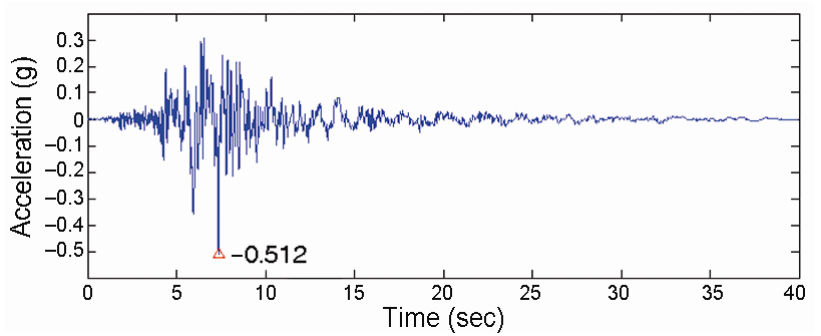

Fig. 4. Loma Prieta earthquake accelerogram (October 17, 1989, Magnitude 7.1)

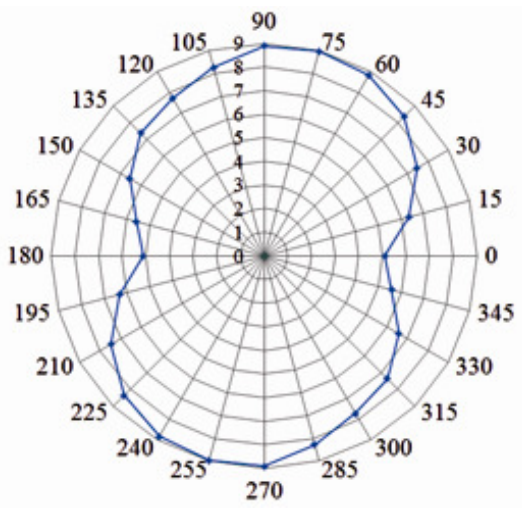

Fig. 5. Maximum absolute joint displacement $(\mathrm{cm})$ for different earthquake incident angles for the 5 -story building 
The critical angle of incidence of 80 degrees is used to compare the 8 sets of equations for PTMD/BTMD tuning parameters presented in Table 1 . The results of the comparisons for maximum absolute displacements, accelerations and base shear are presented in Table 3 .

Based on Table 3, the formulas suggested by Hoang et al. (2008) using $\delta=1$ present the most effective control in decreasing the maximum displacement by $41.3 \%$, maximum acceleration by $35.3 \%$, while formulas suggested by Sadek et al. (1997) result in the highest decrease in absolute base shear by $25.7 \%$.
Results for the maximum inter-story drifts for the eight sets of equations are presented in Figure 6 and for the maximum floor accelerations are presented in Figure 7. Figure 8 shows the maximum displacement and acceleration of joint A6-5 and base shear of the 5-story building with a BTMD system. Equations proposed by Hoang et al. (2008) provide the most effective inter-story displacement control. Equations proposed by Fujino and Abe (1993), Feng and Mita (1995), Sadek et al. (1997), Krenk and Hogsberg (2008) and Hoang et al. (2008) yield similar maximum floor acceleration results and are more effective than the rest of the equations.

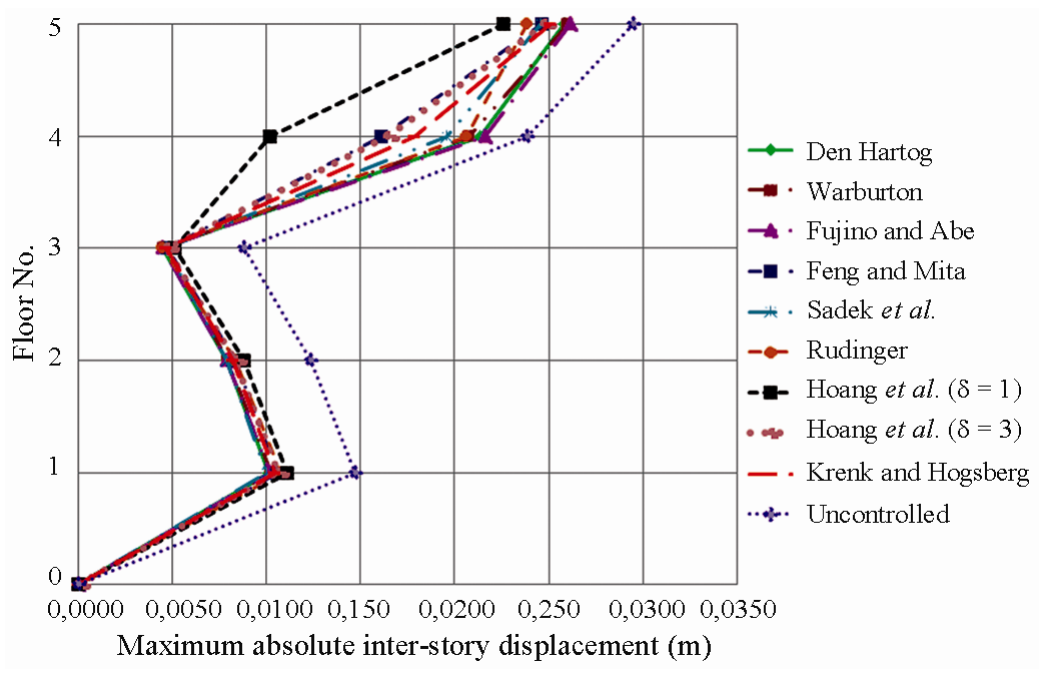

Fig. 6. Maximum interstory displacement (drift) for 5-story building using different equations for optimum TMD tuning parameters

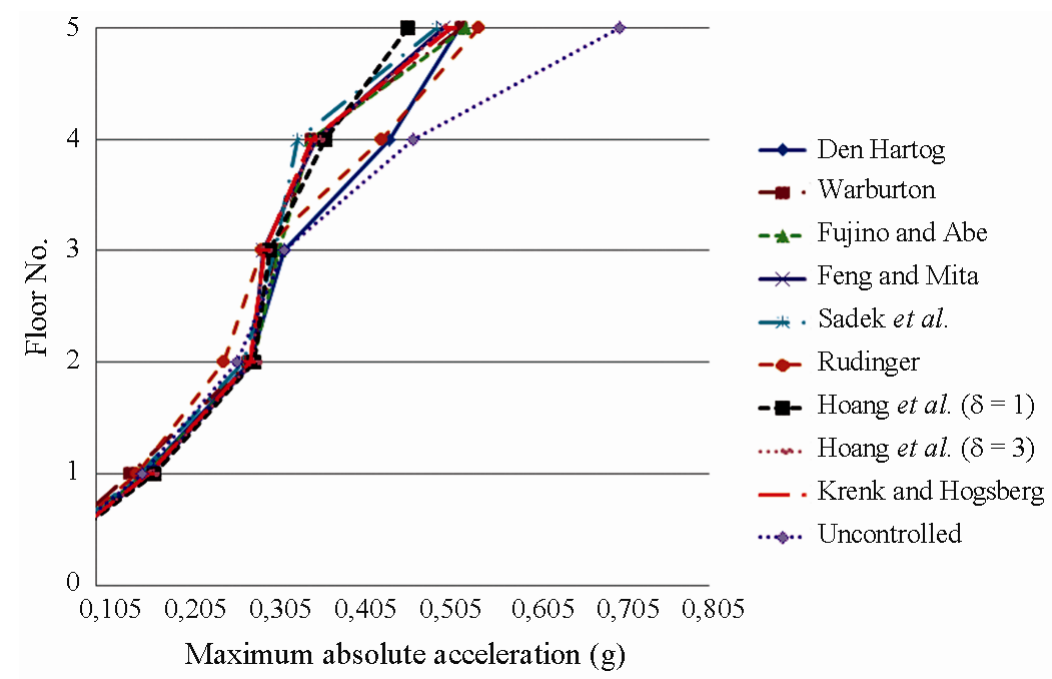

Fig. 7. Maximum absolute floor acceleration for 5-story building using different sets of equations for optimum TMD tuning parameters 
Table 3. Optimum tuning parameters and maximum absolute displacement $(\mathrm{cm})$ and acceleration $(\mathrm{g})$ and base shear $(\mathrm{kN})$ for the 5 -story building

\begin{tabular}{|c|c|c|c|c|c|}
\hline \multirow[b]{2}{*}{ Method } & \multicolumn{2}{|c|}{ Optimal Parameters } & \multicolumn{3}{|c|}{ Maximum Response of the Controlled Structure } \\
\hline & $\begin{array}{c}\text { Frequency ratio } \\
\gamma_{o p t}\end{array}$ & $\begin{array}{c}\text { Damping ratio } \\
\xi_{d o p t}\end{array}$ & $\begin{array}{c}\text { Absolute } \\
\text { Displacement } \\
(\mathrm{cm})\end{array}$ & $\begin{array}{c}\text { Absolute } \\
\text { Acceleration } \\
\left(\mathrm{m} / \mathrm{s}^{2}\right)\end{array}$ & $\begin{array}{c}\text { Absolute } \\
\text { Base Shear } \\
(\mathrm{kN})\end{array}$ \\
\hline Hoang et al. $(2008)(\delta=1)$ & 0.858 & 0.083 & 5.44 & 0.460 & 802.7 \\
\hline Sadek et al. (1997) & 0.963 & 0.219 & 6.37 & 0.494 & 720.2 \\
\hline Feng and Mita (1995) & 0.964 & 0.083 & 6.44 & 0.502 & 764.0 \\
\hline Hoang et al. $(2008)(\delta=3)$ & 0.928 & 0.086 & 6.49 & 0.504 & 763.9 \\
\hline Krenk and Hogsberg (2008) & 0.971 & 0.086 & 6.67 & 0.511 & 754.5 \\
\hline Warburton (1982) & 0.964 & 0.0860 & 6.95 & 0.523 & 745.4 \\
\hline Den Hartog (1956) & 0.971 & 0.101 & 6.96 & 0.520 & 764.2 \\
\hline Fujino and Abe (1993) & 0.964 & 0.0857 & 7.03 & 0.527 & 743.2 \\
\hline Rudinger (2006) & 0.971 & 0.005 & 7.82 & 0.583 & 788.9 \\
\hline Uncontrolled & - & - & 9.27 & 0.710 & 969.6 \\
\hline \multicolumn{3}{|c|}{$\%$ Max. Reduction } & 41.3 & 35.3 & 25.7 \\
\hline
\end{tabular}
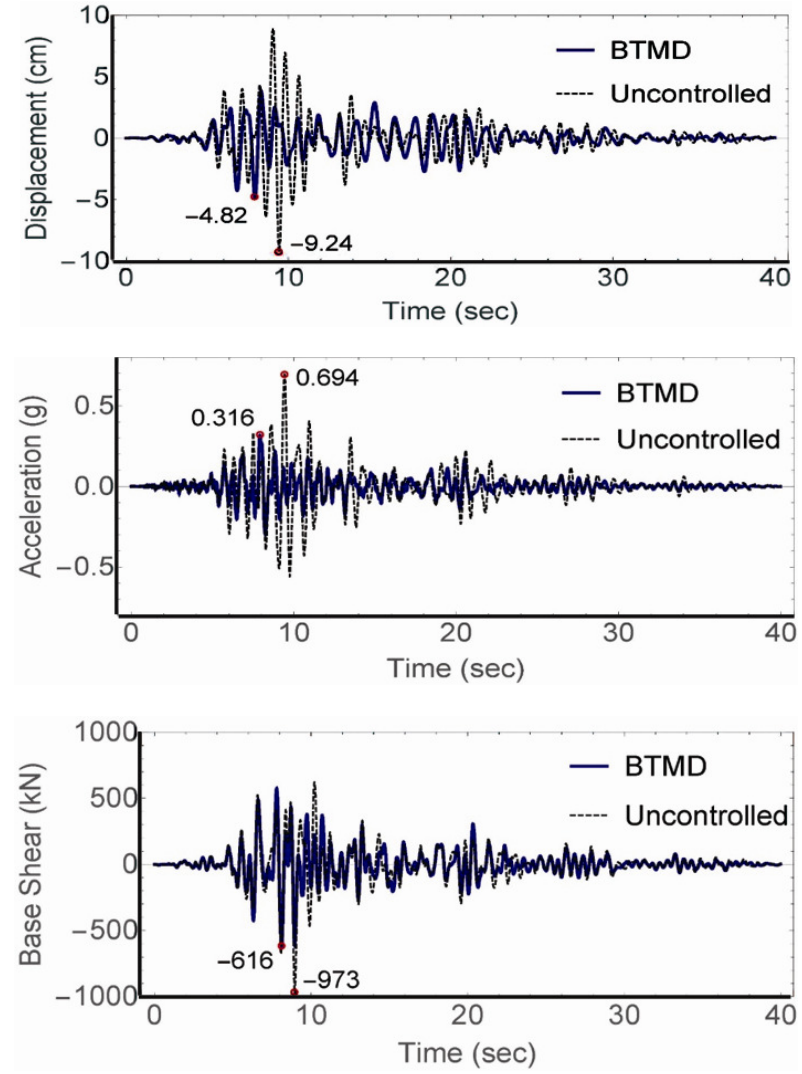

Fig. 8. Maximum displacement and acceleration of joint A6-5 and base shear of 5-story building with a BTMD system

\subsection{Example 2: fifteen-story reinforced concrete moment resisting frame with plan irregularity}

This example is a 15-story irregular reinforced concrete moment-resisting frame with an L-shape plan shown in Figure 9. This building was created originally by Almazan et al. (2012). The beams have a $0.3 \mathrm{~m}$ by $0.7 \mathrm{~m}$ cross- sectional area. All columns have a square $0.5 \mathrm{~m}$ by $0.5 \mathrm{~m}$ cross-sectional area, except columns along grid line 4 which have a $1 \mathrm{~m}$ by $0.4 \mathrm{~m}$ cross-sectional area and grid location C-3 which have a $0.4 \mathrm{~m}$ by $1 \mathrm{~m}$ cross-sectional area. The slab is $0.15 \mathrm{~m}$ thick and is modeled as a rigid diaphragm.

Table 4 presents the free vibrations response data for the uncontrolled structure. This structure is subjected to the same Loma Prieta earthquake accelerogram used in the previous 5-story example (Fig. 4) and studied using 24 different incident angles with increments of 15 degrees in the horizontal plane. The maximum absolute displacement was obtained for the incident angle of 45 degrees with respect to the X-axis (Fig. 9). Next, the incident angle resolution was reduced to 5 degrees around the incident angle of 45 degrees between 45 and 60 degrees.
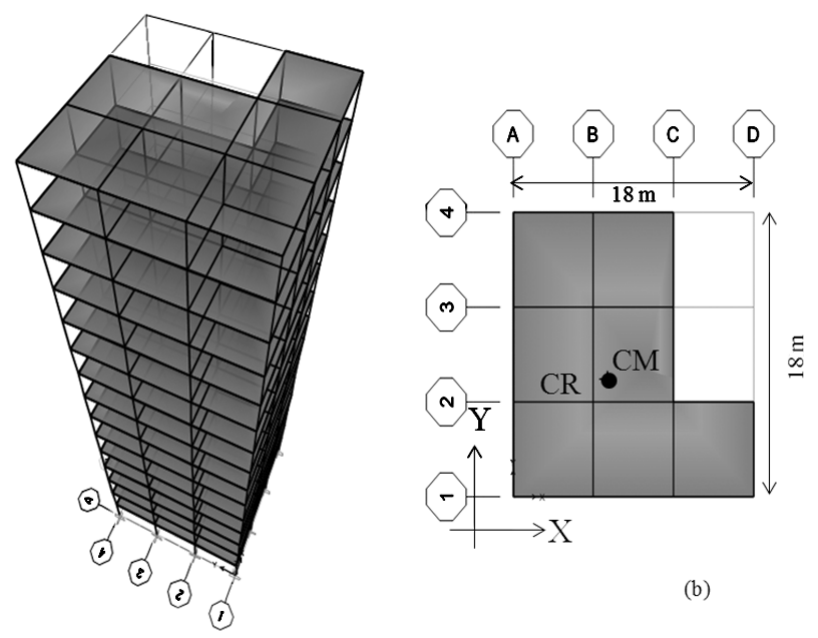

(b)

Fig. 9. 15-story building reinforced concrete 3D building with plan irregularity: (a) Perspective view; (b) Plan view; $+\mathrm{CR}=$ center of rigidity; $\bullet \mathrm{CM}=$ center of mass 
Table 4. Free vibration modal response of the 15-story irregular building

\begin{tabular}{c|c|c|c|c}
\hline \multirow{2}{*}{ Mode } & \multirow{2}{*}{$\begin{array}{c}\text { Period } \\
(\mathrm{sec})\end{array}$} & \multicolumn{3}{|c}{ Modal Mass Participation Factors } \\
\cline { 3 - 5 } & & $\begin{array}{c}\mathrm{X} \\
\text { Translation }\end{array}$ & $\begin{array}{c}\mathrm{Y} \\
\text { Translation }\end{array}$ & $\begin{array}{c}\mathrm{Z} \\
\text { Torsion }\end{array}$ \\
\hline 1 & 2.933 & 0.006 & 0.781 & 0.187 \\
\hline 2 & 2.875 & 0.774 & 0.006 & 0.296 \\
\hline 3 & 2.317 & 0.001 & 0.000 & 0.289 \\
\hline 4 & 0.946 & 0.000 & 0.099 & 0.028 \\
\hline 5 & 0.918 & 0.099 & 0.000 & 0.029 \\
\hline 6 & 0.739 & 0.002 & 0.000 & 0.044 \\
\hline 7 & 0.533 & 0.000 & 0.037 & 0.013 \\
\hline 8 & 0.513 & 0.036 & 0.000 & 0.007 \\
\hline 9 & 0.407 & 0.002 & 0.000 & 0.021 \\
\hline & Total Sum $=$ & 0.921 & 0.925 & 0.915 \\
\hline
\end{tabular}

The maximum absolute displacement was obtained for the incident angle of 50 degrees at joint D1-15. The maximum absolute joint displacements in $\mathrm{cm}$ for different earthquake incident angles are also plotted in Figure 10. This angle of incidence is used to compare the eight sets of equations for TMD tuning parameters presented in Table 1. The results of the comparisons for maximum absolute displacements, accelerations and base shear as well as detailed values of the optimum tuning parameters for the eight sets of equations are presented in Table 5.

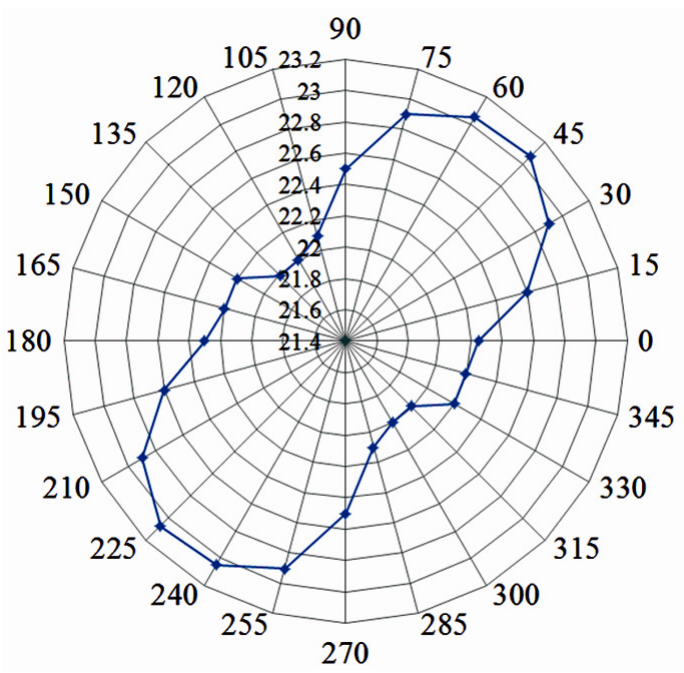

Fig. 10. Maximum absolute displacement $(\mathrm{cm})$ per earthquake incident angles of 15-story building

Equations proposed by Sadek et al. (1997) are the most effective in reducing the structural response, shaded in Table 5. Equations proposed by Hoang et al. (2008) and Krenk and Hogsberg (2008) yield the next best results. Equations presented by Sadek et al. (1997) decrease the maximum absolute displacement by $49.76 \%$, maximum acceleration by $32.14 \%$, and absolute base shear $(\mathrm{kN})$ by $42.22 \%$.

\subsection{Example 3: twenty-story steel moment resisting frame with plan irregularity}

This example is a 20-story steel moment resisting frame structure with plan irregularity created originally by Liew et al. (2001) and used by Jiang et al. (2002) for plastic analysis of steel 3D buildings. This example is also used by Jiang and Adeli (2005) and Adeli and Jiang (2009) in their dynamic wavelet neural network model for structural system identification, Van Long and Hung (2008) for local buckling determination during plastic analysis, and Chiorean (2009) for development of a computer program for nonlinear inelastic analysis.
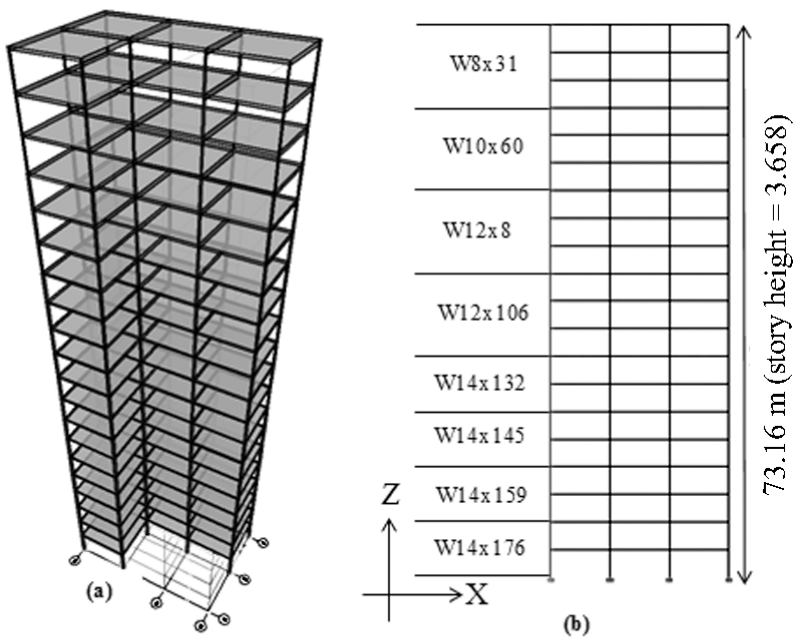

$$
\begin{aligned}
& \mathrm{G} 1=W 12 \times 26 \\
& \mathrm{G} 2=W 16 \times 36 \\
& \mathrm{G} 3=W 21 \times 57
\end{aligned}
$$

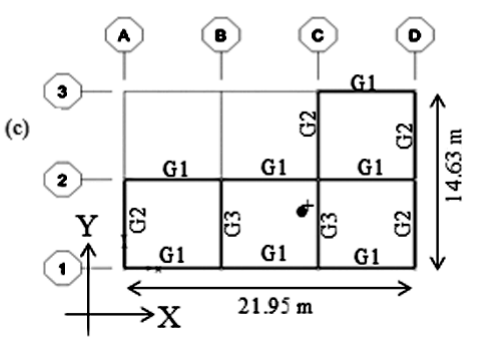

Fig. 11. 20-story building with plan irregularity: (a) Perspective view; (b) Elevation; and (c) Plan view; $+\mathrm{CR}=$ center of rigidity; $\bullet \mathrm{CM}=$ center of mass

The perspective, elevation and plan view of this building are shown in Figure 11. Roof and floor framing systems consist of steel beams and lightweight concrete with a slab thickness of $0.15 \mathrm{~m}$ over steel metal deck working as a rigid diaphragm (Fig. 11c). The building is designed for a combination of $4.8 \mathrm{kN} / \mathrm{m}^{2}$ static gravity load and $0.96 \mathrm{kN} / \mathrm{m}^{2}$ wind load acting on the y-direction. Table 6 presents the free vibrations response data for the uncontrolled structure including the modal mass participation factors. This structure is also subjected to the same Loma Prieta earthquake accelerogram displayed in Figure 4. The maximum displacement was found at joint D320 on the roof. The maximum absolute joint displacements in $\mathrm{cm}$ for different earthquake incident angles are also plotted in Figure 12. The critical angle of earthquake incidence for the uncontrolled structure was determined to be 5 degrees with respect to the $\mathrm{X}$ axis (Fig. 11c). This angle of incidence is used to compare the eight sets of 
equations for TMD tuning parameters presented in Table 1 . The results of the comparisons for maximum absolute displacements, accelerations and base shear as well as detailed values of the optimum tuning parameters for the eight sets of equations are included in Table 7.

Similar to Example 2, equations proposed by Sadek et al. (1997) yield the most effective vibration reductions for the 20-story irregular structure; they decrease the maximum absolute displacement by $43.4 \%$, maximum acceleration by $41.8 \%$, and absolute base shear $(\mathrm{kN})$ by $25.3 \%$.

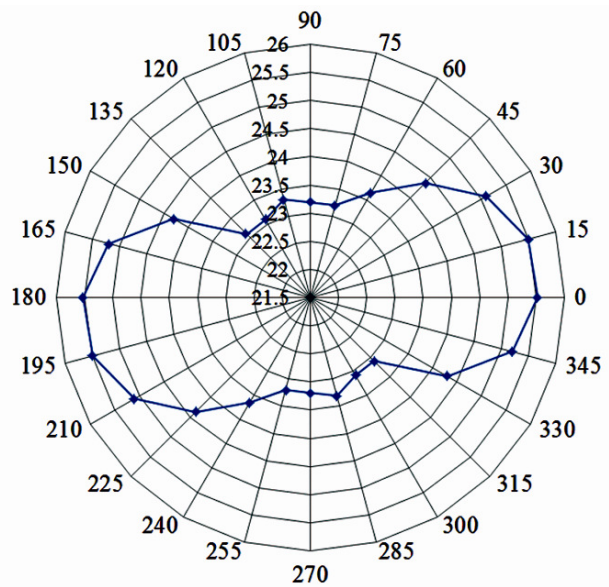

Fig. 12. Maximum absolute joint displacement $(\mathrm{cm})$ per earthquake incident angles for the 20 -story building

Table 5. Optimum tuning parameters and maximum absolute displacement $(\mathrm{cm})$, acceleration $(\mathrm{g})$ and base shear $(\mathrm{kN})$ response for the 15 -story building

\begin{tabular}{|c|c|c|c|c|c|}
\hline \multirow[b]{2}{*}{ Method } & \multicolumn{2}{|c|}{ Optimal Parameters } & \multicolumn{3}{|c|}{ Maximum Response of the Controlled Structure } \\
\hline & $\begin{array}{c}\text { Frequency ratio } \\
\gamma_{o p t}\end{array}$ & $\begin{array}{c}\text { Damping ratio } \\
\xi_{d o p t}\end{array}$ & $\begin{array}{l}\text { Absolute Displacement } \\
(\mathrm{cm})\end{array}$ & $\begin{array}{l}\text { Absolute Acceleration } \\
(\mathrm{g})\end{array}$ & $\begin{array}{l}\text { Absolute Base } \\
\text { Shear }(\mathrm{kN})\end{array}$ \\
\hline Den Hartog (1956) & 0.971 & 0.101 & 14.7 & 0.128 & 1011 \\
\hline Warburton (1982) & 0.964 & 0.086 & 13.5 & 0.128 & 922.6 \\
\hline Fujino and Abe (1993) & 0.964 & 0.086 & 13.5 & 0.128 & 922.6 \\
\hline Feng and Mita (1995) & 0.964 & 0.083 & 13.56 & 0.129 & 925.5 \\
\hline Sadek et al. (1997) & 0.963 & 0.219 & 11.31 & 0.124 & 792.9 \\
\hline Rudinger (2006) & 0.971 & 0.005 & 14.89 & 0.128 & 1003 \\
\hline Hoang et al. (2008) $(\delta=1)$ & 0.858 & 0.083 & 14.09 & 0.124 & 1022 \\
\hline Hoang et al. (2008) $(\delta=3)$ & 0.928 & 0.086 & 13.68 & 0.130 & 930.3 \\
\hline Krenk and Hogsberg (2008) & 0.971 & 0.085 & 13.58 & 0.129 & 920.0 \\
\hline Uncontrolled & - & - & 22.52 & 0.228 & 1372.2 \\
\hline
\end{tabular}

Table 6. Free vibration modal response of the 20 -story irregular building

\begin{tabular}{c|c|c|c|c}
\hline \multirow{2}{*}{ Mode } & \multirow{2}{*}{$\begin{array}{c}\text { Period } \\
\text { (sec })\end{array}$} & X Translation & Y Translation & Z Torsion \\
\cline { 2 - 5 } & 4.666 & 0.756 & 0.001 & 0.121 \\
\hline 1 & 4.256 & 0.001 & 0.718 & 0.444 \\
\hline 2 & 3.659 & 0.002 & 0.000 & 0.166 \\
\hline 3 & 1.707 & 0.000 & 0.127 & 0.088 \\
\hline 4 & 1.647 & 0.101 & 0.000 & 0.010 \\
\hline 5 & 1.396 & 0.000 & 0.000 & 0.021 \\
\hline 6 & 1.043 & 0.000 & 0.054 & 0.037 \\
\hline 7 & 0.981 & 0.040 & 0.000 & 0.005 \\
\hline 8 & 0.853 & 0.000 & 0.000 & 0.009 \\
\hline 10 & 0.728 & 0.000 & 0.025 & 0.017 \\
\hline 11 & 0.679 & 0.023 & 0.000 & 0.003 \\
\hline
\end{tabular}


Table 7. Optimum tuning parameters and maximum absolute displacement $(\mathrm{cm})$, acceleration $(\mathrm{g})$ and Base Shear $(\mathrm{kN})$ response for the 20 -story building

\begin{tabular}{|c|c|c|c|c|c|}
\hline \multirow[b]{2}{*}{ Method } & \multicolumn{2}{|c|}{ Optimal Parameters } & \multicolumn{3}{|c|}{ Maximum Response of the Controlled Structure } \\
\hline & $\begin{array}{c}\text { Frequency ratio } \\
\gamma_{o p t}\end{array}$ & $\begin{array}{c}\text { Damping ratio } \\
\xi_{d o p t}\end{array}$ & $\begin{array}{l}\text { Absolute Displacement } \\
(\mathrm{cm})\end{array}$ & $\begin{array}{c}\text { Absolute Acceleration } \\
(\mathrm{g})\end{array}$ & $\begin{array}{c}\text { Absolute Base } \\
\text { Shear }(\mathrm{kN})\end{array}$ \\
\hline Den Hartog (1956) & 0.971 & 0.101 & 18.77 & 0.188 & 378.2 \\
\hline Warburton (1982) & 0.964 & 0.086 & 16.11 & 0.188 & 378.1 \\
\hline Fujino and Abe (1993) & 0.964 & 0.086 & 16.11 & 0.188 & 378.1 \\
\hline Feng and Mita (1995) & 0.964 & 0.083 & 16.15 & 0.177 & 378.5 \\
\hline Sadek et al. (1997) & 0.963 & 0.219 & 14.45 & 0.167 & 349.5 \\
\hline Rudinger (2006) & 0.971 & 0.005 & 18.31 & 0.179 & 395.9 \\
\hline Hoang et al. $(2008)(\delta=1)$ & 0.858 & 0.083 & 17.55 & 0.179 & 393.8 \\
\hline Hoang et al. $(2008)(\delta=3)$ & 0.928 & 0.086 & 17.25 & 0.179 & 389.5 \\
\hline Krenk and Hogsberg (2008) & 0.971 & 0.085 & 16.10 & 0.187 & 377.8 \\
\hline Uncontrolled & - & - & 25.53 & 0.287 & 466.2 \\
\hline
\end{tabular}

\section{Concluding remarks}

An innovation of this research is vibration control of irregular three-dimensional highrise building structures using the bidirectional TMD (BTMD). A key issue for effective implementation of the BTMD is the determination of their tuning parameters. The second novelty of this research is an investigation of eight different sets of equations for tuning the parameters of TMDs for highrise building structures with both plan and elevation irregularities. To the best of the authors' knowledge such a comparative study has not been reported in the literature previously.

Equations proposed by Hoang et al. (2008) yield the best result for the 5-story irregular structure and those proposed by Sadek et al. (1997) yield the best results for the 15 - and the 20- story irregular buildings. In Tables 3 , 5 , and 7 it is observed that Sadek et al. (1997) yields a relatively large value for the optimum damping ratio, 0.219 , which shows the impact of this ratio in the TMD tuning equations for flexible structures with a fundamental period of vibrations of, say, greater than 1 second ( $\mathrm{T}>1 \mathrm{sec})$.

By examining the displacement, acceleration and base shear results, it is observed the performance of the BTMD in reducing the vibration responses is affected by the rigidity of the structure; it is more effective for taller and more flexible structures. Sadek et al. (1997) equations appear to be more suitable for structures with a fundamental period of vibrations greater than one second.

\section{References}

Acharya, U. R.; Vinitha Sree, S.; Alvin, A. P. C.; Suri, J. S. 2012. Application of non-linear and wavelet based features for the automated identification of epileptic EEG signals, International Journal of Neural Systems 22(2): 1250002-1250016.

http://dx.doi.org/10.1142/S0129065712500025

Adeli, H.; Jiang, X. 2009. Intelligent infrastructure: neural networks, wavelets and chaos theory for intelligent transportation systems and smart structures. Boca Raton, Florida, USA: CRC Press, Taylor \& Francis. 440 p.
Adeli, H.; Kim, H. 2004. Wavelet-hybrid feedback least mean square algorithm for robust control of structures, Journal of Structural Engineering 130(1): 128-137. http://dx.doi.org/10.1061/(ASCE)07339445(2004)130:1(128)

Adeli, H.; Saleh, A. 1999. Control, optimization, and smart structures: high-performance bridges and buildings of the future. New York, USA: John Wiley and Sons. 288 p.

Adeli, H.; Sarma, K. 2006. Cost optimization of structures Fuzzy logic, genetic algorithms, and parallel computing. West Sussex, UK: John Wiley and Sons. 222 p. http://dx.doi.org/10.1002/0470867353

Adeli, H.; Soegiarso, R. 1999. High-performance computing in structural engineering. Boca Raton, Florida, USA: CRC Press. 272 p.

Aldemir, U.; Yanik, A.; Bakiogl, M. 2012. Control of structural response under earthquake excitation, Computer-Aided Civil and Infrastructure Engineering 24(8): 620-638. http://dx.doi.org/10.1111/j.1467-8667.2012.00776.x

Almazan, J. L.; De la Llera, J. C.; Inaudi, J. A.; Lopez Garcia, D.; Izquierdo, L. E. 2007. A bidirectional and homogeneous tuned mass damper: a new device for passive control of vibrations, Engineering Structures 29(7): 1548-1560. http://dx.doi.org/10.1016/j.engstruct.2006.09.005

Almazan, J. L.; Espinoza, G.; Aguirre, J. J. 2012. Torsional balance of asymmetric structures by means of tuned mass dampers, Engineering Structures 42: 308-328.

http://dx.doi.org/10.1016/j.engstruct.2012.04.034

Amini, F.; Khanmohamadi Hazaveh, N.; Abdolahi Rad, A. 2013. Wavelet PSO-based LQR algorithm for optimal structural control using active tuned mass dampers, Computer-Aided Civil and Infrastructure Engineering 28(7): 542-557. http://dx.doi.org/10.1111/mice.12017

ASCE. 2010. Minimum design loads for buildings and other structures - SEI/ASCE Standard No. 7-10. American Society of Civil Engineers. Reston, VA: American Society of Civil Engineers. 650 p.

Bitaraf, M.; Hurlebaus, S.; Barroso, L. R. 2012. Active and semi-active adaptive control for undamaged and damaged building structures under seismic load, Computer-Aided Civil and Infrastructure Engineering 27(1): 48-64. http://dx.doi.org/10.1111/j.1467-8667.2011.00719.x 
Boutalis, Y.; Christodoulou, M.; Theodoridis, D. 2013. Indirect adaptive control of nonlinear systems based on bilinear neuro-fuzzy approximation, International Journal of Neural Systems 23(5): 1350022-1350039.

http://dx.doi.org/10.1142/S0129065713500226

Branco, M.; Guerreiro, L. M. 2011. Seismic rehabilitation of historical masonry buildings, Engineering Structures 33(5): 1626-1634. http://dx.doi.org/10.1016/j.engstruct.2011.01.033

Cen, Z.; Wei, J.; Jiang, R. 2013. A grey-box neural networkbased model identification and fault estimation scheme for nonlinear dynamic systems, International Journal of Neural Systems 23(6): 1350025-1350041. http://dx.doi.org/10.1142/S0129065713500251

Chiorean, C. G. 2009. A computer method for nonlinear inelastic analysis of 3D semirigid steel frameworks, Engineering Structures 31(12): 3016-3033.

http://dx.doi.org/10.1016/j.engstruct.2009.08.003

Connor, J. J. 2003. Introduction to structural motion control. Upper Saddle River, N. J: Prentice Hall Pearson Education. 704 p.

Den Hartog, J. P. 1956. Mechanical vibrations. New York: McGraw-Hill. 492 p.

El-Khoury, O.; Adeli, H. 2013. Recent advances on vibration control of structures under dynamic loading, Archives of Computational Methods in Engineering 20(4): 353-360. http://dx.doi.org/10.1007/s11831-013-9088-2

Feng, M.; Mita, A. 1995.Vibration control of tall buildings using Mega SubConfiguration, Journal of Engineering Mechanics 121(10): 1082-1088. http://dx.doi.org/10.1061/(ASCE)07339399(1995)121:10(1082)

Fujino, Y.; Abe, M. 1993. Design formulas for tuned mass dampers based on a perturbation technique, Earthquake Engineering and Structural Dynamics 22(10): 833-854. http://dx.doi.org/10.1002/eqe.4290221002

Ghaemmaghami, A.; Kianoush, R.; Yuan, X. 2013. Numerical modeling of dynamic behaviour of annular tuned liquid dampers for applications in wind towers, Computer-Aided Civil and Infrastructure Engineering 28(1): 38-51. http://dx.doi.org/10.1111/j.1467-8667.2012.00772.x

Ghodrati Amiri, G.; Abdolahi Rad, A.; Khorasani, M. 2012. Generation of near-field artificial ground motions compatible with median predicted spectra using PSO-based neural network and wavelet analysis, Computer-Aided Civil and Infrastructure Engineering 27(9): 711-730. http://dx.doi.org/10.1111/j.1467-8667.2012.00783.x

Gutierrez Soto, M.; Adeli, H. 2013. Tuned mass dampers, $A r-$ chives of Computational Methods in Engineering 20(4): 419-431. http://dx.doi.org/10.1007/s11831-013-9091-7

Hemami, H.; Clymer, B. D.; Hemami, M. 2012. Simulation of control and synthesis of a constrained movement towards rehabilitation exercises, Integrated Computer-Aided Engineering 19(4): 351-364. http://dx.doi.org/10.3233/ICA-2012-0411

Hoang, N.; Fujino, Y.; Warnitchai, P. 2008. Optimal tuned mass damper for seismic applications and practical formulas, Engineering Structures 30(3): 707-715. http://dx.doi.org/10.1016/j.engstruct.2007.05.007

Hoang, N.; Warnitchai, P. 2005. Design of multiple tuned mass dampers by using a numerical optimizer, Earthquake Engineering and Structural Dynamics 34(2): 125-144. http://dx.doi.org/10.1002/eqe.413
Hsu, W. Y. 2013. Application of quantum-behaved particle swarm optimization to motor imagery EEG classification, International Journal of Neural Systems 23(6): 13500261350040. http://dx.doi.org/10.1142/S0129065713500263

Igusa, T.; Der Kiureghian, A. 1985. Dynamic characterization of two-degree-of-freedom equipment-structure systems, Journal of Engineering Mechanics ASCE 111(1): 1-19. http://dx.doi.org/10.1061/(ASCE)0733-9399(1985)111:1(1)

Jiang, X.; Adeli, H. 2005. Dynamic wavelet neural network for nonlinear identification of highrise buildings, ComputerAided Civil and Infrastructure Engineering 20(5): 316330. http://dx.doi.org/10.1111/j.1467-8667.2005.00399.x

Jiang, X.; Chen, H.; Liew, J. Y. R. 2002. Spread-of-plasticity analysis of three-dimensional steel frames, Journal of Constructional Steel Research 58(2): 193-212. http://dx.doi.org/10.1016/S0143-974X(01)00041-4

Kang, N.; Kim, H.; Choi, S.; Jo, S.; Hwang, J. S.; Yu, E. 2012. Performance evaluation of TMD under typhoon using system identification and inverse wind load estimation, Computer-Aided Civil and Infrastructure Engineering 27(6): 455-473. http://dx.doi.org/10.1111/j.1467-8667.2011.00755.x

Kim, H.; Adeli, H. 2004. Hybrid feedback-least mean square algorithm for structural control, Journal of Structural Engineering 130(1): 120-127. http://dx.doi.org/10.1061/ (ASCE)0733-9445(2004)130:1(120)

Kim, H.; Adeli, H. 2005a. Hybrid control of smart structures using a novel wavelet-based algorithm, Computer-Aided Civil and Infrastructure Engineering 20(1): 7-22. http://dx.doi.org/10.1111/j.1467-8667.2005.00373.x

Kim, H.; Adeli, H. 2005b. Hybrid control of irregular steel high rise building structures under seismic excitations, International Journal for Numerical Methods in Engineering 63(12): 1757-1774. http://dx.doi.org/10.1002/nme.1336

Ko, H.; Marreiros, G.; Morais, H.; Vale, Z.; Ramos, C. 2012. Intelligent supervisory control system for home devices using a cyber physical approach, Integrated ComputerAided Engineering 19(1): 67-79. http://dx.doi.org/10.3233/ICA-2012-0388

Kodogiannis, V. S.; Amina, M.; Petrounias, I. 2013. A clustering-based fuzzy-wavelet neural network model for shortterm load forecasting, International Journal of Neural Systems 23(5): 1350024-1350042. http://dx.doi.org/10.1142/S012906571350024X

Krenk, S.; Hogsberg, J. 2008. Tuned mass absorbers on damped structures under random load, Probabilistic Engineering Mechanics 23(4): 408-415. http://dx.doi.org/10.1016/j.probengmech.2007.04.004

Lei, Y.; Wu, D. T.; Lin, Y. 2012. A decentralized control algorithm for large-scale building structures, Computer-Aided Civil and Infrastructure Engineering 27(1): 2-13. http://dx.doi.org/10.1111/j.1467-8667.2010.00707.x

Liang, Z.; Lee, G. C.; Dargush, G. F.; Song, J. 2012. Structural damping: applications in seismic response modification. Boca Raton, Florida, USA: CRC Press, Taylor \& Francis. 581 p.

Liew, J. Y. R.; Chen, H.; Shanmugan, N. E. 2001. Inelastic analysis of steel frames with composite beams, Journal of Structural Engineering 127(2): 194-202. http://dx.doi.org/10.1061/(ASCE)07339445(2001)127:2(194)

Lin, C. M.; Ting, A. B.; Hsu, C. F.; Chung, C. M. 2012. Adaptive control for MIMO uncertain nonlinear systems using recurrent wavelet neural network, International Journal of Neural Systems 22(1): 37-50.

http://dx.doi.org/10.1142/S0129065712002992 
Lu, X.; Li, P.; Guo, X.; Shi, W.; Liu, J. 2013. Vibration control using ATMD and site measurements on the Shanghai World Financial Center Tower, The Structural Design of Tall and Special Buildings 23(2): 105-123.

http://dx.doi.org/10.1002/tal.1027

Nawrotzki, P. 2006. Tuned-mass systems for seismic retrofit of buildings, in Proceedings of the Seventh International Congress on Advances in Civil Engineering, 11-13 October 2006, Istanbul, Turkey, 1-8.

Nawrotzki, P. 2008. Tuned-mass systems for the dynamic upgrade of buildings and other structures, in Proceedings of the Eleventh East Asia-Pacific Conference on Structural Engineering \& Construction, 19-21 November 2008, Taipei, Taiwan, 1-9.

Nigdeli, S. M.; Boduroğlu, M. H. 2013. Active tendon control of torsionally irregular structures under near-fault ground motion excitation, Computer-Aided Civil and Infrastructure Engineering 28(9): 718-736. http://dx.doi.org/10.1111/mice.12046

Rigatos, G. G. 2013. Adaptive fuzzy control for differentially flat MIMO nonlinear dynamical systems, Integrated Computer-Aided Engineering 20(2): 111-126. http://dx.doi.org/10.3233/ICA-130421

Rodriguez-Seda, E. J.; Stipanovic, D. M.; Sponga, M. W. 2012. Teleoperation of multi-agent systems with nonuniform control input delays, Integrated Computer-Aided Engineering 19(2): 125-136.

http://dx.doi.org/10.3233/ICA-2012-0396

Rudinger, F. 2006. Optimal absorber with nonlinear viscous power law damping and white noise excitation, Journal of Engineering Mechanics ASCE 132(1): 46-53. http://dx.doi.org/10.1061/(ASCE)0733-9399(2006)132: 1(46)

Sadek, F.; Mohraz, B.; Taylor, A. W.; Chung, R. M. 1997. A method of estimating the parameters of tuned mass dampers for seismic application, Earthquake Engineering and Structural Dynamics 26(6): 617-635.

http://dx.doi.org/10.1002/(SICI)1096-

9845(199706)26:6<617::AID-EQE664>3.0.CO;2-Z
Saleh, A.; Adeli, H. 1997. Robust parallel algorithms for solution of the Riccati equation, Journal of Aerospace Engineering 10(3): 126-133.

http://dx.doi.org/10.1061/(ASCE)0893-1321(1997)10:3(126)

Shafahi, Y.; Bagherian, M. 2013. A customized particle swarm method to solve highway alignment optimization problem, Computer-Aided Civil and Infrastructure Engineering 28(1): 52-67.

http://dx.doi.org/10.1111/j.1467-8667.2012.00769.x

Tao, H.; Zain, J. M.; Ahmed, M. M.; Abdalla, A. N.; Jing, W. 2012. A wavelet-based particle swarm optimization algorithm for digital image watermarking, Integrated Computer-Aided Engineering 19(1): 81-91. http://dx.doi.org/10.3233/ICA-2012-0392

Van Long, H.; Hung, N. D. 2008. Local buckling check according to Eurocode-3 for plastic-hinge analysis of 3-D frames, Engineering Structures 30(11): 3105-3113. http://dx.doi.org/10.1016/j.engstruct.2008.04.002

Villaverde, R. 1985. Reduction in seismic response with heavily-damped vibration absorbers, Earthquake Engineering and Structural Dynamics 13(1): 33-42. http://dx.doi.org/10.1002/eqe.4290130105

Wang, N.; Adeli, H. 2014. Sustainable building design, Journal of Civil Engineering and Management 20(1): 1-10. http://dx.doi.org/10.3846/13923730.2013.871330

Warburton, G. 1982. Optimum absorber parameters for various combinations of response and excitation parameters, Earthquake Engineering and Structural Dynamics 10(3): 381-401. http://dx.doi.org/10.1002/eqe.4290100304

Xiang, J.; Liang, M. 2012. Wavelet-based detection of beam cracks using modal shape and frequency measurements, Computer-Aided Civil and Infrastructure Engineering 27(6): $439-454$. http://dx.doi.org/10.1111/j.1467-8667.2012.00760.x

Young, K.; Adeli, H. 2014. Fundamental Period of irregular moment resisting steel frames, Structural Steel Design of Tall Buildings 23(15): 1141-1157. http://dx.doi.org/10.1002/tal.1112

Mariantonieta GUTIERREZ SOTO. She is currently a PhD degree student in Civil Engineering and a Graduate Teaching Associate at the Engineering Education Innovation Center, College of Engineering Department, at Ohio State University. She received her BS degree in Civil Engineering from Lamar University, Beaumont, Texas in 2010 and her MS in Civil Engineering, with a Structural Engineering focus, in 2012 from Ohio State University. In 2011, she received the Distinguished Graduate Student Women in Engineering Award. Her current research interests include structural control and health monitoring, earthquake engineering and sustainability infrastructure.

Hojjat ADELI. Is Professor of Civil, Environmental, and Geodetic Engineering at the Ohio State University. He has authored/co-authored 285 journal articles in various fields of computer science, engineering, mathematics, and medicine since 1976 when he received his PhD from Stanford University at the age of 26 . He has authored/co-authored 15 books. He also holds a United States patent for his neural dynamic computational model. He is the quadruple winner of The Ohio State University Lumley Outstanding Research Award. In 1998 he received The Ohio State University's highest research honor, the Distinguished Scholar Award "in recognition of extraordinary accomplishment in research and scholarship". In 2005, he was elected Distinguished Member, American Society of Civil Engineers: "for wide-ranging, exceptional, and pioneering contributions to computing in civil engineering and extraordinary leadership in advancing the use of computing and information technologies in many engineering disciplines throughout the world". In 2007, he received the Ohio State University College of Engineering Peter L. and Clara M. Scott Award for Excellence in Engineering Education "for sustained, exceptional, and multi-faceted contributions to numerous fields including computer-aided engineering, knowledge engineering, computational intelligence, large-scale design optimization, and smart structures with worldwide impact", as well as the Charles E. MacQuigg Outstanding Teaching Award. In 2008, he was elected a Fellow of the American Association for the Advancement of Science (AAAS), "for distinguished contributions to computational infrastructure engineering". In 2010 the ASCE journal of Leadership and Management in Engineering profiled him as an Engineering Legend. He is also a Fellow of IEEE and the American Neurological Association. He is the recipient of the 2012 IEEE-EMBS Outstanding Paper Award, Omar Khayyam Research Excellence Award from Scientia Iranica, the Eduardo Renato Caianiello Award for Excellence in Scientific Research, and a Special Medal from the Polish Neural Network Society in Recognition of Outstanding Contribution to the Development of Computational Intelligence. He is the Editor-in-Chief of the international research journal Computer-Aided Civil and Infrastructure Engineering which he founded in 1986. 